GLOBAL JOURNAL OF SOCIAL SCIENCES VOL 15, 2016: 73-86

\title{
GLOBAL TURBULENCE AND NIGERIA'S CITIZEN DIPLOMACY: 2007-2016
}

C. N. ODOCK

(Received 15 November 2016; Revision Accepted 13 December 2016)

\begin{abstract}
Global turbulence and citizen diplomacy is the outcome of our original research project designed to explore the problematic of the extent to which the laudable policy of citizen diplomacy adopted by the Nigerian Government in 2007 has been translated into practice, on the assumption that this development was critical to the empowerment or emancipation of the citizenry. In the course of the research, a new reality came to the fore: the real challenge of Nigeria like most Third World Countries, is not whether citizen diplomacy or any other Social Programme is properly implemented or not, but the difficulties imposed on them and Nigeria in particular, by the fall-outs or consequences of global turbulence, conceived in terms of the multiple processes of change and transformation in the global system associated with globalization: the rise of new actors, the generation of new interests, conflicts and identities that fuel and sustain micro and macro nationalism and pull citizens in divergent directions and dilute loyalty to the nation-state. The activities of Boko Haram symbolize in vivid terms the impact of global turbulence in Nigeria as expressed by global Islam and international terrorism. Relying on a careful reformulation of J. David Singers (1962) Level of Analysis Problem in International Relations, the research came to the conclusion that it was the consequences of global turbulence seen in Boko Haram and other ethnic separatist movements and militias that made it impossible for Nigeria to devote any significant amount of national resources to the prosecution of citizen diplomacy. Although, the policy was designed to significantly impact the country's Diaspora seen as a vital reservoir of assets for Nigeria's national development. The paper ended with a recommendation for the institution of a citizen diplomacy Trust Fund to cover the costs of citizen diplomacy and support the training of Nigerian diplomats to protect the interests of Nigerians abroad.
\end{abstract}

\section{INTRODUCTION}

In 2007 the government of President Musa Yar Adua adopted the policy of citizen diplomacy as a means of correcting the poor image of the country abroad, stemming the poor treatment meted out to Nigerians in the diaspora and tapping into the enormous potential of wealth, expertise, skills, and resources that were available to various Nigerian diaspora groups abroad (Maduekwe 2009). This response was greeted with widespread approval by many Nigerians, even though some skeptics faulted the widely publicized policy orientation as one additional instance of our series of 'myownism' (Pine 2011), or the tendency of each Nigerian government in power to put forth its own brand or new policy orientation without much regard to philosophical justification, logical coherence or policy continuity.

In spite of these difficulties, citizen diplomacy was seen by some observers as Nigeria's modest attempt to join the train of globalization by evolving its own peculiar brand of alternative diplomacy based on giving voice to ordinary citizens, groups and organizations the opportunity to participate in promoting the country's national interest and external relations, and therefore worthy of scientific study. This rationale prompted the present writer to undertake a study of citizen diplomacy and its implementation by the federal government in an

C. N. Odock, Department of Political Science, University of Calabar, Calabar, Cross River State, Nigeria. 
attempt to assess the extent to which the policy has been translated into practice.

\section{In order to carry out this objective, the study raised several questions:}

State the concept of citizen diplomacy in Nigeria and its central objectives?

Examines the theoretical framework and methodological procedures would best enable us study the theory and practice of Citizen Diplomacy in Nigeria?

What are the major findings of our study of citizen diplomacy in Nigeria and what conclusions and recommendations can we draw from our study?

\section{BACKGROUND TO THE STUDY}

One of the legacies of the relatively short-lived administration of the late President Umaru Musa Yar'Adua (2007-2010), was the adoption of the concept of citizen diplomacy as the new focus or thrust of Nigeria's foreign policy in 2007. According to Chief Ojo Maduekwe the Honorable Minister of Foreign Affairs who launched the new policy:

"Citizen Diplomacy is ... about people.... Citizen Diplomacy therefore is a foreign policy initiative that will be citizen oriented in its approach, objective and outcome" (Maduekwe, 2009: 8). This brief statement of the essence of citizen diplomacy was both captivating and refreshing, for it simply shifted the focus and objective of Nigeria's foreign policy from the pursuit of the interests of the Nigerian nation state, its ruling classes and elites, to catering for the interests, demands and aspirations of ordinary Nigerian citizens.

There is no doubt that "citizen diplomacy" conceived in the condensed form stated represents not just a culmination of the shifting emphases of Nigeria's foreign policy from the initial preoccupation with the promotion and protection of the "country's national interests and the welfare and dignity of the black man all over the world," (Olusanya and Akindele, 1986:2-3); to "the idea that Africa is the center piece of Nigeria's foreign policy" (Gambari, 1989: 275); to "beneficial and constructive concentricism" (Akinterinwa, 2004: 444); and then' "new direction in Nigeria's foreign policy"(Adeniji, 2004: 421). It could be termed revolutionary in putting the nation's diplomatic activities squarely at the service of its citizens.
However, laudable as citizen diplomacy might be conceptually, we hasten to add that it is really in the faithful translation of the noble intentions espoused in the concept and translation of citizen diplomacy into real practice by the nation's Ministry of Foreign Affairs and the country's diplomatic missions abroad that the benefits of citizen diplomacy can actually be verified or measured.

Given that it is now several years since the policy of citizen diplomacy was launched by the Nigerian government, it is presently expedient empirically assess the extent to which citizen diplomacy as a new and revolutionary approach to Nigeria's foreign policy has now become the grand norm of our diplomatic practice. In fact, the need for empirically ascertaining the extent to which citizen diplomacy is actually being put into practice is strengthened by the reality that the Honorable Minister who launched citizen diplomacy in 2007 moved in 2010 to occupy a strategic diplomatic post as Nigeria's High Commissioner in Ottawa, Canada for some time. Did he practice what he preached or taught as Honorable Minister? What about other diplomatic missions? What is the status of citizen diplomacy today? How do Nigerians living at home and in the Diaspora assess the theory and practice of citizen diplomacy by the diplomatic missions in the countries where they live?

It is hoped that this research project on the theory and practice of citizen diplomacy will help us find answers to some of the questions raised above. The salience of the questions posed above lies in the fact that they have been the pre-occupation of observers and commentators who have written on various aspects of Nigeria's foreign policy since citizen diplomacy was launched.

\section{STATEMENT OF THE PROBLEM}

Although the adoption of Citizen Diplomacy was widely acclaimed as a new foreign policy orientation by the President Yar Adua administration, its effective implementation over the past several years has been problematic due to the scarcity of funds available to Nigeria and the combination of domestic political instability and the prevalence of global turbulence in the international system.

As shown by Eze (2009), 'citizen diplomacy represents a bold legal step aimed at addressing the abnormal situation where "Nigerians in difficulty abroad were almost seen 
as sheep without shepherds", and therefore a very welcome development from the perspective of ordinary Nigerians. Given the very broad scope of the individuals and groups that were envisaged to participate in the formulation and practice of 'citizen diplomacy' both as actors and beneficiaries (Ogunsanwo, 2009), this policy is novel, worthy of proper study and careful assessment in terms of both the goals and objectives it was designed to achieve as well as the extent to which the intended beneficiaries are actually reaping the anticipated benefits of the policy. This study is therefore designed to undertake both an extensive survey of literature on citizen diplomacy as well as empirically establish the extent to which citizen diplomacy has been really implemented and the obstacles that have hampered the full or successful implementation of the programme.

\section{OBJECTIVES OF THE STUDY}

The objectives of our proposed study of the theory and practice of citizen diplomacy are derived directly from the research questions raised above. Specifically, this research project seeks to:

(i) Clarify the meaning and establish the goals and objectives of citizens diplomacy;

(ii) Identify the key institutions, organizations and actors responsible for the formulation and implementation of citizen diplomacy at home and abroad;

(iii) Determine whether the institutions, organizations and actors listed in (ii) above have or are fulfilling responsibilities assigned;

(iv) Identify any difficulties and obstacles that have prevented the realization of the goals and objectives of citizen diplomacy;

(v) Ascertain the adequacy of resources made available to them.

(vi) Proffer solutions to the challenges and difficulties identified in (iv) above.

\section{HYPOTHESES OF THE STUDY}

Our research project will be guided by the following hypotheses that are couched in the null form:

(i) The policy of citizen diplomacy was not based on any significant philosophical, ideological or political objectives;

(ii) There is no significant relationship between the objectives of citizen diplomacy and the institutional disposition of Nigeria's foreign policy establishment;

(iii) There has not been any significant relationship between the outputs of Nigerian foreign policy and the objectives of citizen diplomacy;

(iv) There have not been any significant obstacles or challenges to the actualization of the objectives of citizen diplomacy;

(iv) There are no significant remedies to the challenges confronting the actualization of citizen diplomacy.

\section{SIGNIFICANCE OF THE STUDY}

A study of Nigeria's foreign policy from the perspective of the theory and practice of citizen diplomacy has great theoretical and empirical significance.

From a theoretical standpoint, our study will provide us an opportunity to evaluate the conceptual soundness and validity of this new addition to Nigeria's long list of foreign policy thrusts, ideological shifts and epistemological gyrations.

More importantly, the theoretic contributions which a study of the theory and practice of citizen diplomacy will add to our understanding of Nigeria's foreign policy is the extent to which it will address the challenges to Nigeria's foreign policy identified by Adebajo and Mustapha (2008), wherein it was claimed that "Nigeria, the most populous country in Africa, is a Gulliver, and the Lilliputians have been Nigeria's leaders, whose petty ambitions and often inhumane greed...have prevented a country of enormous potential from fulfilling its leadership aspirations and development potential." (Adebajo, 2008: 2). In other words, will the practice of citizen diplomacy help to reduce Gulliver's troubles or tame its Lilliputians?

Empirically, it is hoped that this study will provide a contemporary account of the actual practice of Nigeria's foreign policy as seen from the vantage point of drivers of the country's diplomacy.

\section{LITERATURE REVIEW}

Based on the suggestion by Pautasso (2013),this literature review is divided into three (3) main areas namely: Citizen Diplomacy as a new paradigm in the study of foreign policy; a comparative study of citizen diplomacy in other regions and national settings; and finally, citizen 
diplomacy as a feature of Nigeria's foreign policy.

It is important to note that the repartition of our literature review proposed above is different from other approaches which focus on treating the literature review in terms of each of the research questions. By adopting a three-fold division rather than other thematic approaches, our procedure is obviously more parsimonious and therefore enhances a more condensed treatment of the subject matter.

\section{Citizen Diplomacy: A new paradigm in the study of foreign policy.}

A good starting point for our survey of literature on citizen diplomacy is to note that this concept is actually a synonym of what is known in the literature as public diplomacy or the "new diplomacy" (Melissen 2005). In broad terms, the new diplomacy has to do with the increased interest and attention which the public or citizens at large in most countries of the world and, especially the United States of America have continued to show in the diplomacy of their countries as a result of what happened in the USA on September 11, 2001 as well as the American war in Iraq. Consequently Melissen noted that "public diplomacy was beyond doubt the hottest item in the US foreign policy establishment", although "for many other countries, they became interested in public diplomacy long before ' $9 / 11$ ' and for very different reasons" (Melissen 2005:XX). This statement can be interpreted as meaning that citizen diplomacy is now a global process, with each country having its own unique reasons for it.

We turn to Riordan (2005) for some answers to others questions. According to the author, "the new security agenda requires a more collaborative approach to foreign policy, which in return requires a new dialogue-based paradigm for foreign policy" (Riordan 2005: 180). The quintessence of this new paradigm is that the dialogue based foreign policy must go beyond the communication of government to government as carried out by diplomats, but also embrace non-governmental organizations and civil society and its representatives. The author justifies this approach by noting that some contemporary challenges such as the global war on terrorism, nation building, environmental degradation, the spread of epidemic diseases, financial instability, organized crime, migration and resource and energy issues require effective and broader dialogue and collaboration between societies where government and state agents might be considered suspect and lack credibility. In other words, ordinary citizen or groups might be the best representatives of a country depending on the issues at stake and the interests that need to be secured.

The Routledge Handbook of Public Diplomacy edited by Nancy Snow and Philip M. Taylor (2009), is definitely a major source of information on the new paradigm of public diplomacy. According to the editors of the volume, The Routledge Handbook of Public Diplomacy was first conceived in 2004 as a project to provide "a comprehensive overview of public diplomacy and national image and perception management, enabling an understanding of its 21st Century revival to informed members of the public as well as academics and traditional practitioners" (Snow and Taylor 2009:IX). But how objective could this Handbook be if it left out any mention of Africa?

In her contribution to the volume titled: "Rethinking Public Diplomacy", Nancy Snow, one of the Volume's editors traced the origin of public diplomacy to the work of Joseph Nye on "Soft Power" Nye (2005); which is based on "intangible or indirect influences such as culture, values and ideology." Essentially Soft power which Snow defined as to "attract and co-opt" (Snow 2009:3), contrasts sharply with the first two ways of applying power, namely to "coerce with threats", and to "induce behavioural change with payments" (Snow 2009:3).

Snow's chapter could be credited with the foresight of predicting the election of president Obama in 2009 as a solution to America's problem of rebranding; and an answer to the public diplomacy challenge of the United States (Snow 2009:5-6). She provides us this conception of public diplomacy: Public diplomacy involves the way in which both government and private individuals and groups influence directly and indirectly those public attitudes and opinions that bear directly on another government's foreign policy decisions people to people (P2P) (Snow 2009:6).

Mueller (2009:102) defines citizen diplomacy specifically as "the concept that the individual citizen has the right, indeed, the responsibility to help shape[US] foreign relations' one hand shake at a time" "Citizen diplomats are generally defined as being unofficial ambassadors who participate in exchange programmes overseas as host and interact with interventional exchange programme participants in the United States". This definition of citizen 
diplomacy although largely correct in a formal sense can be faulted as being overly US centred, because it is obvious that the two processes identified by the author as indicative of the essence of citizen diplomacy can be located in the diplomatic practice of most of the advanced and even developing countries, although the nature, extent and degree would differ.

\section{Citizen Diplomacy in Other Contexts}

One pointer to the reality that citizen diplomacy has become a new paradigm in the study and practice of contemporary international relations and foreign policy, is the fact that it is being increasingly employed in the management and explanation of the relations of various actors including major powers, regional contenders and rivals and even among states competing for scarce resources or divided by old rivalries, animosities, and prejudices.

In this section therefore, we examine a number of publications that demonstrate the wide spread use of citizen diplomacy in the foreign policy of states. A journal article published by Eastwood (2007) is very relevant to our review on the use of citizen diplomacy as a strategy of foreign policy by states because it is not only built on the origin and development of citizen diplomacy outlined by Mueller (2009 originally published in 2006), but outlines the application of the soft power of citizen diplomacy in the development of education cities by American universities in the Arab world, precisely Doha Qatar. This specific application of citizen diplomacy in establishing university campuses in the Middle East for the transfer of technology runs in tandem with other strategies also identified by Eastwood such as cultural exchange, the development of sister-cities etc, (See Eastwood 2007: 447). As reported by Eastwood, Education City near Doha, Qatar. " features five new American branch campuses" designed to "mend the science deficit" in the Arab world. [Eastwood 2007: 446]. The expectation is that these institutions could:

- develop a full presence in the Middle East

- assist in the education of a new generation of Middle Eastern Students

- by these efforts open the doors for new understanding, etc, (p446).

It is important to note that these outcomes cannot be guaranteed in advance.

A study of citizen diplomacy as applied to a specific region of the world is the Journal article by Aviva Shemesh titled: "Citizen Diplomacy creating a culture of peace: The Israeli Palestinian Case" (Shemesh 2012). This work is very significant for reason that in addition to reporting the specific application of citizen diplomacy to the Israeli - Palestinian conflict in the face of the stagnation of the Oslo peace process, the paper informs on the evolution and continuous refinement of citizen diplomacy as a concept and analytical tool.

Given the protracted nature of the Israeli - Palestinian conflict in the Middle East region of the world, it is no surprise that conflict has generated a strong interest in the recourse to citizen diplomacy as an instrument of advancing the quest for peace where official track 1 diplomacy seems to be stagnant or moving at snail speed. It is in this perspective that we note here the 2013 contribution to the literature by Lee Yaniv, a student of the University of California, whose paper " people-to-people Peace-making: The Role of Citizen Diplomacy in the Israeli Palestinian Conflict was adjudged the "Best Student Paper 2013/CPD Paper Prize.

\section{Works that deal with Citizen Diplomacy in Nigeria.}

As we have indicated in our introductory statement, although citizen diplomacy is the latest of the many approaches, thrusts, emphases and directions in the study of Nigeria's foreign policy, it can only be properly understood in the context of the evolution of the country's external relations since independence: whether in the first twenty-five years (Olusanya and Akindele, 1986; Akinyemi, Agbi and Otubanjo, 1989) or beyond the first fifty years, (Eze, 2010). The reason is that the country's foreign policy since independence has been described in terms of a constant search proper set of external goals and aspirations that will at the same time mobilize a strong enough domestic coalition of forces to ensure external success. This connection between citizen diplomacy and Nigeria's foreign policy as was emphasized by Agbu (2007). Saliu (2010: 316) has examined the development of citizen diplomacy in relation to other "thrusts of Nigerian foreign policy", pointing out its historical setting in the development of the nation's foreign policy.

This constant adoption of new directions and thrusts in Nigerian foreign policy has been designated as a continuous outpouring of "myownisms" seen by Pine (2011) as comprising "a plethora of conceptual ideological transitions in 
the Nigeria foreign policy machinery" which are "often regime specific and borne out of a psychological hunger to carve a regime identity that will create and leave lasting impressions on the minds of Nigerians." Myownism" is a coinage of Attah Pine (2011) designating the tendency of every Nigerian administration to adopt a foreign policy orientation that is uniquely its own. This is often done with little or no regard to the consistency, relevance and harmony of the new policy with the policies already adopted by past governments. This often results in what policy planners and implementers refer to either as policy inconsistency, policy summersaults or conflicting policies. The net effect of this tendency is to lead to the abandonment of laudable policies or their haphazard implementation, all to the detriment of the country and its citizenry; (Author's findings, 2016).We wish to note that although changes in a nation's foreign policy should not be embarked upon for the mere fun of doing, changes in policy direction and orientation are often responses to new challenges and developments, which could have deleterious effects if not responded to.

It is therefore necessary that we highlight briefly some of these antecedent "thrusts" in Nigeria's foreign policy as necessary background to our study. Many of the environmental conditions and institutional processes that conditioned the initial definition, formulation and implementation of Nigeria's foreign policy soon after independence and up to the first twenty five years and the major thrusts of foreign policy have been highlighted in (Olusanya and Akindele, 1986; Akinyemi, Agbi and Otubanjo 1989 and Olusanya and Akindele, 1990).

By highlighting the costs and benefits of foreign policy, the former Minister of Foreign Affairs returned to a preoccupation of Nigeria's foreign policy since the late 1980s: how to make the country's foreign policy respond to Nigeria's changing economic fortunes. To address this question, the Nigerian Institute of International Affairs, Lagos had published The Economic Diplomacy of the Nigerian State in 1991, which was reprinted in 2002. In addition to defining the domestic and international contexts of Nigeria's economic diplomacy, the editors of the volume outlined the main tenets of Nigeria's economic diplomacy to include:

The necessity for a more direct linkage to be established between Nigeria's domestic economic requirements and its foreign policy with a view to ensuring that the 1atter (foreign policy) served the needs of the former (domestic economic requirements) more systematically (Ogwu and Olukoshi, 2002: 16).

Akinterinwa (2010: VII) has noted that the adoption of Citizen Diplomacy as a thrust of Nigeria's foreign policy gave rise to some debate among diplomatists and scholars for and against "citizen diplomacy as thrust of Nigeria's foreign policy. His own work on the subject titled: "Nigerian Citizen Diplomacy: Theoretical Genesis and Empirical Exegesis" can be considered a major contribution to the domestic debate on Citizen Diplomacy in Nigeria. The author rightly situates the problematic of his large volume as follows: Referring to the subject of citizen diplomacy, he raised the question: "as official policy, what does it mean in theory and in practice? What is it that can be achieved for the Citizens of Nigeria as a result?" (Akinterinwa 2010).

This work presents a comprehensive survey of the conceptual, theoretical and practical dimensions of Citizen Diplomacy in Nigeria. The reader can find in this volume answers to some of the questions surrounding the conception, design and implementation of Citizen Diplomacy up to 2010, when the author's work was published. The objective of our study is somehow different; not to provide a comprehensive overview of the subject but to access the degree of transformation of theory to practice. In the final chapter of his book Nigeria's Citizen Diplomacy: Theoretical Genesis and Empirical Exgensis, Akinterinwa (2010:198ff and especially 221-226), raised several challenges that relate to the implementation of Citizen Diplomacy in Nigeria. Among these challenges are fist the challenge of coordination of citizen diplomacy to ensure that it is the duty and responsibility of both the government and its MDAs as well as all the citizens to implement citizen diplomacy; he also identified the challenge of "deliberate frustration by many diplomatic missions accredited to Nigeria of genuine Nigerian applications for visa" (P. 222).

In this regard, a useful contribution in the Guidelines for newly appointed ambassadors is the chapter written by Ambassador Joe Keshi on the topic: "Rethinking the Nigerian Diaspora Project" (139-158). In this chapter, the writer makes a forceful case for all Nigerian ambassadors and heads of Missions to constructively engage the Nigeria Diaspora Communities in their Countries of posting. The crux of his argument is that: The Nigerian 
Diaspora . . . is and remains a source and strong resource base that we can tap into to bridge the skill gaps, the experience gaps, the entrepreneurial gaps, etc; that Nigeria needs for national economic transformation (Keshi 2013: 149).

We need to note here that it was our strongly held view that given the numerical significance and extant contributions to national development as amply demonstrated by Keshi in this chapter (P.140-144), the way the Nigerian missions abroad related to and transacted with members of the Nigerian Diaspora abroad would contribute a significant index of the translation of Citizen Diplomacy into practice. It is interesting that in accounting for some of the reasons that have contributed to the formation of a large Nigerian Diaspora abroad Ambassador Keshi made reference to the "political and economic turbulence at home" (P. 142).

It is within this context for example that we include Monday Dickson's (2010) Journal article, "Assessing Citizen Diplomacy in President Umaru Musa Yar Adua'a Nigeria 2007-2009." The author declared in the paper that: the adoption of Citizen Diplomacy by the Federal Government does not seem to have changed the poor perception about Nigeria because of the inability of Nigeria's leadership to clearly define her national interest. (Dickson 2011: abstract P. 1). It is not clear whether the author was correct in affirming that Nigeria's leadership was unable to define clearly our national interest. It appears that the writer was taking the country's emphases on the more concrete aspects of national interest such as maintaining the sovereignty territorial integrity of the country over the ideological or ideational aspirations of national interest Citizen Diplomacy as lack of clarity.

Our literature review cannot be complete without evoking a growing body of knowledge that explores the impact of domestic instability, insecurity and insurgency on Nigeria's foreign policy: (Venda 2015; Imhonopi and Urim 2016; Amalu 2016; and Kabsina 2011). The major thrust of this corpus of writings is that domestic insecurity and insurgency have had a tremendous impact on the nation's external relations which cannot be ignored.

It is worthy of note that most of these authors rightly attribute the phenomenon of domestic insurgency to the global forces of transnational Islamic fundamentalism.

\section{THEORETICAL FRAMEWORK FOR THE STUDY}

In this regard, I would like to note that many Nigerian scholars of international relations have often adopted a uni-dimensional application of Singer's (1962) formulation of the levels of analysis problematic. They have tended to follow the bottom-up format of the level of analysis formulation whereby they begin from the internal or domestic processes of individual nations, to the international system. Hence the individual characteristics of national actors are used to interpret the extent to which they harness the national resources of geography, economic, military and governance characteristics, which they deploy in the international system to the advantage or disadvantage of their countries (See for example, Idang 1973; Gambari 1980; and Ajibola 1978). While this scenario was largely correct in the pre-globalization era, a new schema now begs for consideration. In the globalization era, global events or phenomena impact on geographic regions and nation states, thereby forcing or obligating national actors to find suitable responses. This scenario can be captured by the top-to-bottom dynamic shown on figure below.

In effect the bottom-up flow and the topto-bottom dynamic represent two complementary and reciprocal dimensions of the level of analysis dynamics as shown in Fig I. 
FIG 1:

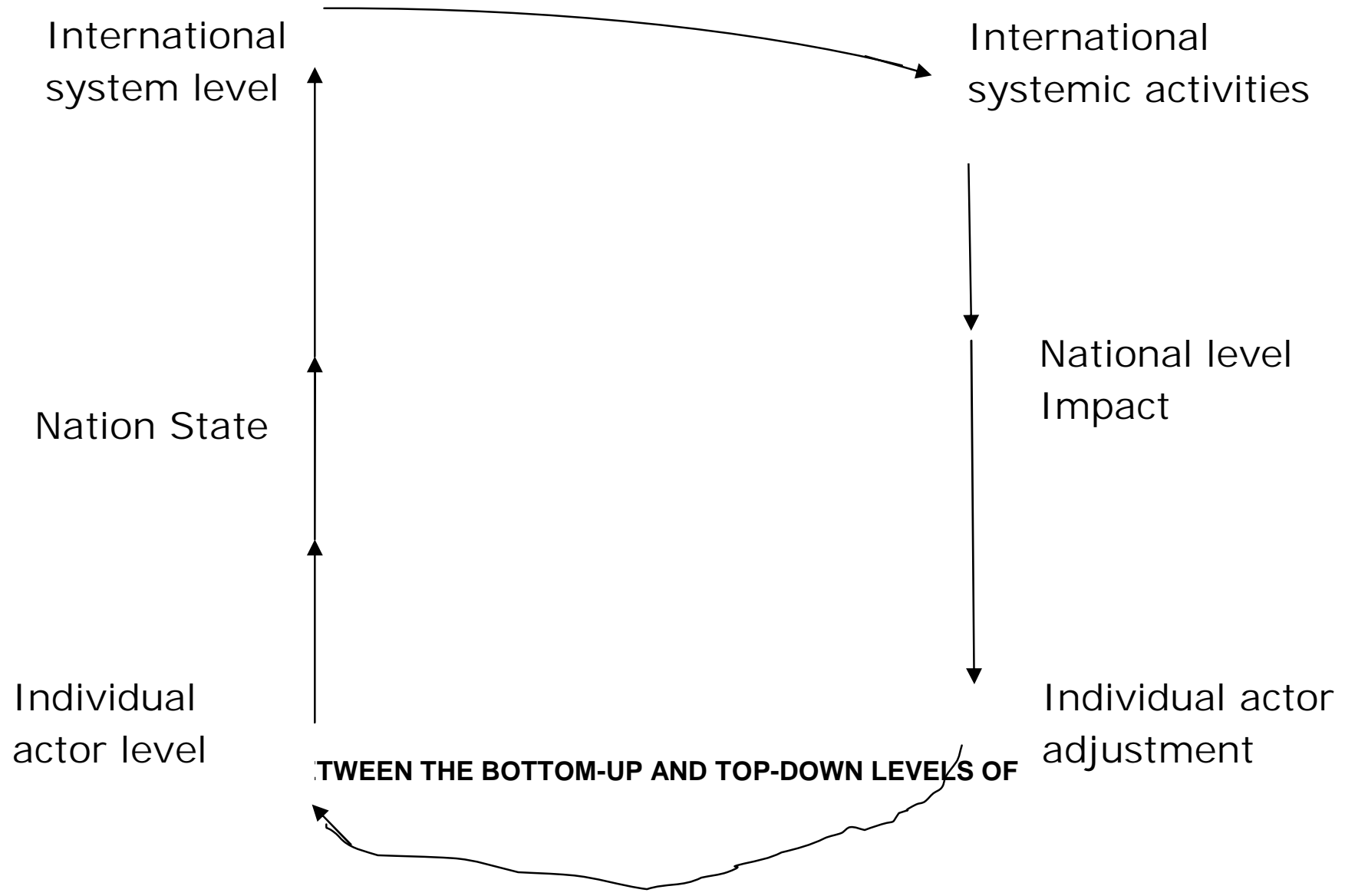

Note: Based on this figure, Nigeria's foreign policy since the end of the Cold War can be analyzed largely in terms of the reciprocal flow between the two sides of the figure, with the right side of the flow. Essentially most Nigerian leaders and governments have been devising remedies to these challenges arising form he international system, whether it is climate change, international terrorism, cyber crimes and traffic in naiveties and drugs.

\section{METHODOLOGY OF THE STUDY}

This study adopted the empirical descriptive survey research method which combined the use of primary data generated by the researcher in the Ministry of Foreign Affairs with an in-depth analysis of the available documentary sources in books, journals and credible Internet sources. The original design for this study included a plan to administer structured questionnaires to actors at the Ministry of Foreign Affairs and a number of diplomatic missions abroad. Logistic problems related to funding and visas, led the researcher to limit his research to the Directorate of Research at the headquarters of the Ministry of Foreign
Affairs and discuss with some senior colleagues at the Nigerian Institute of International Affairs. However, the responses to our questionnaire provided by the Directorate of Research proved to be adequate to clarify many of the issues connected to our research. Those responses form the basis of our findings reported below.

\section{FINDINGS OF THE STUDY}

This study came up with the following major findings:

i. Citizen diplomacy has become a worldwide phenomenon studied and 
carried out in many countries under different names such as;

(a) The New diplomacy

(b) Peoples diplomacy

(c) Non official diplomacy

(d) Multi-track diplomacy

ii. The adoption of citizen diplomacy initially evoked widespread enthusiasm and popular support in Nigeria as an additional means of bringing governance closer to the people.

iii. The Federal Ministry of Foreign Affairs has adopted Citizen Diplomacy as a guiding principle in Nigeria's external relations by making the interest of Nigerian citizens the core value and interest of its ministry and the diplomatic mission abroad.

iv. However, the ministry has not received any specific or additional funding since inception of the policy in 2007.

v. A major cause of the poor funding of not just the Ministry of Foreign Affairs, but most of the social programmes and policies of the Nigerian government has been the Boko Haram insurgency in Nigeria's North-East region since 2009 and the militancy in the Niger Delta region, all of which appear to have elevated national security and defence to the fore of national interest.

\section{CONCLUSION}

This paper examined the problematic of the translation of Nigeria's foreign policy orientation of citizen diplomacy into practice using an empirical descriptive research design. The literature review showed that citizen diplomacy is really a new paradigm of the practice of foreign policy world-wide, with different countries using it to accomplish diverse and multiple objectives. Our research showed that citizen diplomacy has been a long standing underlying principle and practice in Nigeria's external relations, especially when Chief Henry Fajemirokun helped General Gowon drive the establishment of ECOWAS in 1972-75. This can be interpreted as indicating that although the terminology of citizen diplomacy is a relatively recent innovation, its practice may be fairly old in Nigeria. Thus the new emphasis on citizen diplomacy in Nigeria and elsewhere agrees with recent global trends whereby states not only seek to respond to the challenges posed by globalization through their official diplomatic channels, but by multiplying the tracks by which they seek to influence other actors. However, this quest to follow the trend of globalization in Nigeria was constrained by the negative effects of global turbulence as represented by micronationalism and macro-nationalism leading to the development of ethnic militias, religious fanaticism and insurgency, with Boko Haram and the Niger Delta Avengers being typical examples.

From a theoretical perspective, the paper brought out clearly the need for us to refocus our usage of the three levels of analyses formulation by not only considering the internal variables but the impact of global forces on the domestic setting of Third World countries.

Empirically the paper shows that adoption of the new policy orientation has not provoked major changes in the institutions and infrastructure of Nigeria's foreign policy nor received any special funding. Given the reality that funding is central to the actualization of any worthy objective; the paperused the impact of global turbulenceto account for this limitation. We came to the conclusion that in order to account for the lack of funding for citizen diplomacy and other social programmes of the Nigerian State, these policies and programmes need to be located in the context of global turbulence originating from globalization whose fall-outs in terms of micro and macro nationalism, transnational ideological and religious movements, and especially, international terrorism challenge the sovereignty, territorial integrity and national identity of most Third World countries. These challenges eventually consume a disproportionate share of national resources in defence and security expenses, leaving little or nothing for social programmes such as citizen diplomacy.

\section{RECOMMENDATIONS}

1. Since citizen diplomacy is now largely the practice in Nigeria's foreign policy, there is need back it up with some special funding whether from the Government or from ordinary Nigerian citizens. A special Citizen Diplomacy bond issued by the Central Bank, and which interested Nigerian citizens could subscribe be floated to meet this special need. This will truly make citizen diplomacy policy- a people's policy. 
2. If and when such public funds are made available to the mission to clear their indebtedness and drive citizen diplomacy, there will need to be put in place an effective mechanism for monitoring how the missions operate and the extent to which they comply with the exigencies of citizen diplomacy.

3. If as we have argued in this paper, the real problematic of citizen diplomacy is not the opposition between its theory and practice, but between the demands imposed on Nigeria and other Third World Countries by the repercussions and fall outs of global turbulence, then there is strong need for researchers to redirect the focus of their research to a study of how developments in the international system impact on the domestic policies of these countries.

\section{REFERENCES}

David Singer, J.,1962. "The Level of Analysis problem in International Relations" World Politics. 14, (1):

Adebayo Adekeye., 2008. "Hegemony on a shoestring: Nigeria's post cold war foreign policy", Chapter 1 in Gulliver's Troubles: Nigeria's Foreign Policy after the Cold War, edited by Adekeye Adebajo and Abdul Raufu Mustapha, Scottsville S.A., University of Kwa ZuluNatal Press.

Ogunsanwo Alaba., 2009. "Citizen Diplomacy: Challenges for Nigeria's Foreign Policy" Chapter 1, in Citizen Diplomacy, edited by Osita C. Eze, Lagos, Nigerian Institute of International Affairs.

Pine Atah., 2011. "Nigeria Foreign Policy, 19602011: Fifty one years of conceptual confusion on" www.modernghana.com. Site visited on Wednesday July 10, 2013.

Akinterinwa, Bola A., 2010. "Concentricisim in Nigeria's Foreign Policy", Chapter 21 in Nigeria's New Foreign Policy Thrusts: Essays in Honour of Ambassador Oluyemi Adeniji, CON, edited by Bol A. Akinterinwa, Ibadan, Vantage Publishers Ltd.
Olusanya, G. O and Akindele, R. A., 1986. "The fundamentals of Nigeria's foreign policy and external economic relations", Chapter 1 in Nigeria's External Relations: The First Twenty-Five Years, Ibadan: University Press Limited.

Saliu, Hassan A., 2010. Citizen diplomacy and the future of Nigeria's foreign policy, Chapter 13 in: Beyond Fifty Years of Nigeria's Foreign Policy: Issues, Challenges and Prospects edited by Osita Eze, Lagos, the Nigerian Institute of International Affairs.

Ibrahim, Gambari., 1989. Nigerian Foreign Policy at the Cross Roads: Concepts, Critical Issues and Management of External Affairs under the Buhari Administration. Chapter 15 in Nigeria since Independence: The First Twenty-Five Years Volume $X$ International Relations, edited by A. B. Akinyemi, S. 0. Agbi and A. 0. Otubanjo, Ibadan, Heinemann Educational Books Nigeria Limited for the Panel on Nigeria Since Independence History Project.

Ojo, Maduekwe., 2009. "Keynote Address: Citizen Diplomacy" in Citizen Diplomacy, edited by Osita C. Eze, Lagos: Nigerian Institute of International Affairs.

Oluyemi, Adeniji., 2004. "New Directions in Nigeria's Foreign Policy" Chapter 20 in, Nigeria's New Foreign Policy Twists: Essays in Honour of Ambassador Oluyemi Adeniji, CON, edited by Bola A. Akinkerinwa, Ibadan: Vantage Publishers Ltd.

Rosenau, J. N., 1990. Turbulence in World Politics; A theory of Change and Continuity. Princeton, Princeton University Press.

Agbu, Osita., 2009. "Nigerian Foreign Policy under President Umaru Musa Yar-'Adua: Challenges and Prospects", Chapter 3 in Citizen Diplomacy, edited by Prof. Osita C. Eze, Lagos, Nigerian Institute of International Affairs.

Osita, C. Eze., 2010. "Citizen Diplomacy, Bold Legal Perspective, National/International 
Perspective" Chapter Two in Citizen Diplomacy, edited by Osita C. Eze, Lagos, Nigerian Institute of International Affairs.

Osita, C. Eze., 2009. "Foreword in Citizen Diplomacy", edited by Osita C. Eze, Lagos, Nigerian Institute of International Affairs.

Ogwu, Joy U and Olukoshi, Adebayo., 2002. "Nigeria's Economic Diplomacy: Some Contending Issues" Chapter 1 in: The Economic Diplomacy of the Nigeria State, edited by U. Joy Ogwu and Olukoshi 0.Adebayo, Lagos, Nigerian Institute of International Affairs.

Shemesh, A., 2012. Citizen Diplomacy creating a culture of peace: the IsrealiPalestincian Case" Palestine- Isreal Journal of Politics, Economics and culture, 18, (23): 58-66.

Lee, Yaniv., 2013. People-to-People Peace Making: the Role of Citizen Diplomacy in the Isreali-Palestinian Conflict" United of Southern California. Center on Public Diplomacy, Best Student Paper.

Jan, Melissen., (ed) 2005. The New Diplomacy: soft Power in International Relations, Palgrane/Macmillian.

Shaun, Riordan., 2005. Dialogue based Public Diplomacy: A new Foreign Policy Paradigm" chapter in: The New Diplomacy: soft power in International Relations edited by Jan Melissan, Palgrave Macmillian.

Akinterinwa, Bola A., 2010. Nigeria's Citizen Diplomacy: theoretical Genesis and empirical Express, Ibadan, Bolytag International Publishers.

Martin Uhomoibhi and Ehiedu Iweriebor., 2013. Effective and Affimative Representation of Nigeria: Guidelines for newly appointed Ambassadors, edited by Martin Uhomoibhi and Ehiedu Iweriebor (2013), Ibadan, Book Builders' editions Africa.
Monday Dickson., 2010. "Citizen Diplomacy in President Umaru Musa Yar Adua's Nigeria 2007-2009: an assessment", International Journal of Politics and good Governance, (1-3): Quarter 111 2010.

Eastwood, Brant M.,2007. "A note on the new face of Citizen Diplomacy: Education City and American Universities in the Middle East", American Foreign Policy Interests, 29: 443-449.

Routledge Handbook of Public DiplomacyBehavioural Dynamics Institute, edited by Nancy Snow and Philip M. Taylor (2009).

Gambari, I. A., 1980. Party Politics and Foreign Policy: Nigeria under the First Republic. Zaria, Nigeria. Ahmadu Bello University Press.

Ajibola, William A., 1978. Foreign Policy and Public Opinion: A case study of British Foreign Policy over the Nigerian Civil War. Ibadan, Ibadan University Press.

Idang, Gordon J.,1973. Nigeria: Internal Politics and Foreign Policy 1960-1966.

Pautasso, M., 2013. Ten Simple Rules for Writing a Literature Review; - NCBINational Institutes of Health. www.ncbi.nim.nih.govspmc3715443.int ernet site visited in July 2016.

Onyemaechi, Augustine Eke and Ezurium, Gerald Ekenedirichukwu., 2015. "Terrorism and National Security: Constructing the Socio-Economic Dynamics in Nigeria". Studies in Politics and Society. Vol. 3, No. 1, December 2015, 145-171.

Okeke, V. O. S and Aniche, E. T., 2014. "Internal Political Environment of Nigerian foreign policy and Implentation of Citizens Diplomacy" under Yar'Adua/Jonathan Administration (2007-2011): A Linkage Political Approach, American Journal of Social Issues and Humanities. 4, (1):

Amalu, Nneka Sophie., 2015. "Impact of Boko Haram Insurgency on Human Security 
in Nigeria". Global Journal of Social Sciences, 14, 35-42.

Balogun, M. J., 2011. "Route to Power, Nigeria, Lagos, Malthouse Press.

Deutsch, Karl W., 1998. The Analysis of International Relations, New Delhi, Prentice,-Hall Private Limited.

Haas, Ernest B., 1976. "Turbulent Fields and the Theory of Regional Integration". International Organization, 30, (2): Spring 1996: 173-212.

Folarin, Sheriff.,2011. "Nigeria's New CitizenCentered Diplomacy". Any lessons from the United States. Covenant University Portal.

Odoh, S. I and Nwogbaga, David M. E., 2014. "Reflection on the theory and practice of Citizen Diplomacy in the Conduct of Nigeria's Foreign Policy". Journal of Humanities and Social Science. 19, (10): 9-14.

Venda, Terma Loryu., 2015. "Terrorism and Nigeria's Foreign Policy: A discourse". Intellectual Tourist. 2, (5): 1-7.
Dickson, Monday., 2010. "Citizen Diplomacy in President Umaru Musa Yar'Adua's Nigeria 2007-2009: an assessment". International Journal of Politics and Good Governance. (1-3): Quarter III 2010.

Imhonopi, David and Urim, Ugochukwu Moses., 2016. "The Spectre of Terrorism and Nigeria's Industrial Development: A Multistake holder Imperative." African Journal of Criminology and Justice Studies (AJCJS). 9, (1): May 2016: 20-40.

Odock, C. N., 2010. "Contemporary Political Analysis: The Case of a Critical Theory of Society". Revue Africaine d'Etudes Politiques et Strategiques. (7): 43-60.

Nye, Joseph., 2005. "Soft Power: The Means to Success in World Politics". Paperback. Amazon Books online.

Katsina, Muktar Katsina., 2011. "The Oil Factor in the United States War on Terrorism". Nigerian Journal of International Affairs. 37, (3): September-December, 2011. 


\section{APPENDIX}

Table 1: Top recipient countries of remittances (in billion of US Dollars)

\begin{tabular}{|l|l|l|l|l|l|l|l|}
\hline Country & $\begin{array}{l}\text { Remittanc } \\
\text { es (2009) }\end{array}$ & $\begin{array}{l}\text { Remittanc } \\
\text { es (2009) }\end{array}$ & $\begin{array}{l}\text { Remittanc } \\
\text { es (2009) }\end{array}$ & $\begin{array}{l}\text { Remittanc } \\
\text { es (2009) }\end{array}$ & $\begin{array}{l}\text { Remittanc } \\
\text { es (2009) }\end{array}$ & $\begin{array}{l}\text { Remittanc } \\
\text { es (2009) }\end{array}$ & $\begin{array}{l}\text { Remittanc } \\
\text { es (2009) }\end{array}$ \\
\hline India & 53.20 & 53.48 & 62.50 & 68.82 & 69.97 & 70.97 & 72.20 \\
\hline China & 41.60 & 52.46 & 61.58 & 57.99 & 59.49 & 61.49 & 63.90 \\
\hline $\begin{array}{l}\text { Philippin } \\
\text { es }\end{array}$ & 19.96 & 21.56 & 23.05 & 24.61 & 26.70 & 27.90 & 29.70 \\
\hline France & 16.06 & 19.46 & 22.56 & 22.05 & 23.34 & 23.94 & 24.60 \\
\hline Mexico & 22.08 & 22.08 & 23.59 & 23.37 & 23.02 & 24.50 & 25.70 \\
\hline Nigeria & 18.37 & 19.82 & 20.62 & 20.63 & 20.89 & 20.88 & 20.89 \\
\hline Egypt & 7.15 & 12.45 & 14.32 & 19.24 & 17.83 & 19.83 & 20.40 \\
\hline Germany & 21.34 & 12.79 & 14.52 & 15.14 & 15.20 & 16.60 & 17.50 \\
\hline Pakistan & 8.72 & 9.69 & 12.26 & 14.01 & 14.63 & 17.80 & 20.10 \\
\hline $\begin{array}{l}\text { Banglade } \\
\text { sh }\end{array}$ & 10.74 & 11.28 & 12.96 & 14.24 & 13.86 & 15.10 & 15.80 \\
\hline Belgium & 10.44 & 10.29 & 10.98 & 10.16 & 11.11 & 11.11 & 11.10 \\
\hline Vietnam & 6.02 & 8.26 & 8.60 & 10.00 & 11.00 & 11.80 & 12.30 \\
\hline Ukraine & 5.94 & 6.54 & 7.82 & 8.45 & 7.67 & 8.45 & 6.20 \\
\hline Spain & 8.95 & 9.10 & 9.92 & 9.66 & 9.58 & 10.10 & 10.50 \\
\hline $\begin{array}{l}\text { Indonesi } \\
\text { a }\end{array}$ & 6.79 & 6.92 & 6.92 & 7.21 & 7.62 & 8.66 & 10.51 \\
\hline
\end{tabular}

Source: Mohapatra, Ratha, \& Silwal, A. (2010); Wikipedia (2016)

Table 2: Nigeria's diaspora remittances per GDP (2009-2015)

\begin{tabular}{|l|l|l|l|}
\hline Year & Estimated diaspora population & $\begin{array}{l}\text { Total amount of } \\
\text { diaspora remittances } \\
\text { (USD billion) }\end{array}$ & $\begin{array}{l}\text { Remittances as \% of } \\
\text { GDP }\end{array}$ \\
\hline 2009 & $15,000,000$ & 18.37 & 6.0 \\
\hline 2010 & $15,000,000$ & 19.82 & 5.4 \\
\hline 2011 & $15,000,000$ & 20.62 & 5.0 \\
\hline 2012 & $15,000,000$ & 20.63 & 4.5 \\
\hline 2013 & $15,000,000$ & 20.89 & 4 \\
\hline 2014 & $15,000,000$ & 20.88 & 3.7 \\
\hline 2015 & $15,000,000$ & 20.89 & 4.3 \\
\hline
\end{tabular}

Source: Mohapatra, Ratha, \& Silwal, A. (2010); Wikipedia (2016); nigeriadiaspora.com (2016). 


\begin{tabular}{|l|l|l|l|l|l|}
\hline \multicolumn{9}{|c|}{ Table 3: Nigeria's FG Budget (2009-2016) } \\
\hline Year & Budget (N) & Defence budget (N) & $\begin{array}{l}\text { Foreign Affairs } \\
\text { budget }\end{array}$ & $\begin{array}{l}\% \text { Share } \\
\text { of } \\
\text { Defence }\end{array}$ & $\begin{array}{l}\% \\
\text { of } \\
\text { Foreign } \\
\text { Affairs }\end{array}$ \\
\hline 2009 & $3,049,000,000,000$ & & & & \\
\hline 2010 & $4,400,000,000,000$ & & & & \\
\hline 2011 & $4,200,200,000,000$ & & & & \\
\hline 2012 & $4,749,100,821,170$ & $326,354,184,382$ & $50,186,470,959$ & 6.9 & 1.1 \\
\hline 2013 & $4,987,000,000,000$ & $364,415,146,885$ & $71,602,678,070$ & 7.3 & 1.4 \\
\hline 2014 & $4,695,300,000,000$ & $373,452,095,037$ & $46,595,745,004$ & 7.9 & 1 \\
\hline 2015 & $4,460,000,000,000$ & $358,466,078,698$ & $47,495,358,240$ & 8.03 & 1.06 \\
\hline 2016 & $6,077,680,000,000$ & $294,525,795,702$ & $40,663,193,241$ & 4.84 & 0.66 \\
\hline
\end{tabular}

Source: Federal Ministry of Finance (2012); Federal Ministry of Finance (2013); Federal Republic of Nigeria (2014). 